\title{
Mortality of inhabitants in an area polluted by cadmium: 15 year follow up
}

M Nishijo, H Nakagawa, Y Morikawa, M Tabata, M Senma, K Miura, H Takahara, S Kawano, M Nishi, K Mizukoshi, T Kido, K Nogawa

\begin{abstract}
Objective-To assess the influence of environmental exposure to cadmium (Cd) on long term outcome of inhabitants living in an area polluted by $\mathrm{Cd}$.

Methods-A follow up study for 15 years (from 1974-5 to 1991) was carried out on 2408 inhabitants (amounting to $95 \%$ of the target population, 1079 men and 1329 women) of the Kakehashi River basin in Ishikawa Prefecture, Japan. These inhabitants had been the subjects of the health impact survey in 1974-5 to evaluate (by measurement of urinary retinol binding protein (RBP)) renal dysfunction induced by $\mathrm{Cd}$. Analysis of mortality was performed by dividing subjects into a urinary $R B P$ positive ( $\geqslant 4 \mathrm{mg} / \mathrm{l}$ ) group and RBP negative ( $<4 \mathrm{mg} / \mathrm{l})$ group.

Results-After adjustment for age with Cox's proportional hazard model, RBP $\geqslant 4 \mathrm{mg} / \mathrm{l}$ showed a significant relation to mortality in both sexes. At this time, the mortality risk ratio of the RBP positive to negative group was 1.71 in the men and 1.42 in the women. When the SMRs according to causes of deaths in the RBP positive group were compared with those of the RBP negative group or the overall Japanese population increases of SMR for cardiovascular diseases, especially heart failure, and renal diseases were found in both sexes.

Conclusion-These results suggest that the prognosis of the exposed inhabitants with renal tubular dysfunction is unfavourable, and these increases of mortality are due to heart failure and renal diseases.
\end{abstract}

(Occup Environ Med 1995;52:181-184)

Keywords: environmental cadmium; retinol binding protein; mortality

Renal tubular dysfunction is well known as an adverse health effect of environmental cadmium (Cd) exposure, and is characterised by the increased urinary excretion of low molecular weight proteins. Kakehashi River basin in Ishikawa Prefecture has been designated as one of the areas polluted by Cd in Japan. ' The source of pollution was an upstream copper mine closed in 1971. The Health Authorities of Ishikawa Prefecture conducted a health impact survey in $1974-5$ by measuring urinary retinol binding protein (RBP) in morn- ing urine samples and found a high prevalence of urinary RBP positive ( $\geqslant 4 \mathrm{mg} / \mathrm{l}$ ) subjects among the inhabitants living in the polluted Kakehashi River basin aged $>50$ years. ${ }^{1}$

We followed up the subjects targeted in this 1974-5 health survey for seven years and found that the mortality of the urinary RBP positive group was higher than that of the urinary RBP negative $(<4 \mathrm{mg} / \mathrm{l})$ group in men. ${ }^{2}$ We also reported that the mortality of a urinary $\beta_{2}$-microglobulin positive group was higher than that of a $\beta_{2}$-microglobulin negative group in both sexes in a nine year follow up study of the subjects in the 1981-2 health impact survey in the same area. ${ }^{3}$

In the seven year follow up study since the 1974-5 health impact survey, differences in survival rates according to age group and cause of death could not be adequately examined because of small numbers of deaths due to the short observation period. In the follow up study of the remaining subjects of the 1981-2 study, those with severe renal tubular dysfunction may have already died by 1981-2.

Against this background, we conducted a 15 year follow up study of the subjects of the 1974-5 examination, and attempted to determine the long term prognosis of $\mathrm{Cd}$ induced renal tubular dysfunction with urinary $R B P$ as an index.

\section{Subjects and methods}

In August 1974 and from March to April 1975 the Ishikawa Prefectural Health Authority conducted a two part health impact survey among the inhabitants aged $\geqslant 50$ years in the Cd polluted Kakehashi River basin in Ishikawa Prefecture. A total of 2408 people (1079 men and 1329 women) participated in these surveys, which represented $95.4 \%$ of the target population. At the time of the surveys, early morning urinary RBP was measured semiquantitatively by electrophoresis with a cellulose acetate membrane. Table 1 shows the age distribution of the subjects at

Table 1 Prevalence of $R B P \geqslant 4 \mathrm{mg} / \mathrm{l}$ in three age groups

\begin{tabular}{|c|c|c|c|c|}
\hline & \multicolumn{2}{|l|}{ Men } & \multicolumn{2}{|c|}{ Women } \\
\hline & $n$ & $\begin{array}{l}R B P \\
\geqslant 4 \mathrm{mg} / l(\%)\end{array}$ & $n$ & $\begin{array}{l}R B P \\
\geqslant 4 \mathrm{mg} / \mathrm{l}(\%)\end{array}$ \\
\hline $\begin{array}{l}50-59 \\
60-69 \\
70-\end{array}$ & $\begin{array}{l}483 \\
365 \\
231\end{array}$ & $\begin{array}{l}15(3 \cdot 1) \\
24(6 \cdot 6) \\
36(15 \cdot 6)\end{array}$ & $\begin{array}{l}564 \\
452 \\
313\end{array}$ & $\begin{array}{l}10(1 \cdot 8) \\
30(6 \cdot 6) \\
73(23 \cdot 3)\end{array}$ \\
\hline Total & 1079 & $65(6 \cdot 0)$ & 1329 & $113(8 \cdot 5)$ \\
\hline
\end{tabular}


Table 2 Analysis of urinary RBP and mortality with Cox's proportional hazard model

\begin{tabular}{llllcl}
\hline Index & Coefficient & SEM & Hazard ratio $(95 \%$ CI) $\neq$ & $\chi^{2}$ & P value \\
\hline Men: & & & & & \\
Age & 1.064 & 0.055 & $2.90(2.60-3.23)$ & 362.82 & $<0.001$ \\
RBP† & 0.337 & 0.155 & $1.40(1.04-1.90)$ & 4.76 & $<0.05$ \\
& & & & & \\
Women: & & 0.052 & $3.23(2.92-3.58)$ & 506.97 & $<0.001$ \\
Age & 1.173 & 0.124 & $1.59(1.25-2.03)$ & 14.15 & $<0.001$ \\
RBP† & 0.466 & &
\end{tabular}

* Age has been coded as follows: $50-59=1,60-69=2,70-79=3, \geqslant 80=4$; + RBP has been coded as follows: $\mathrm{RBP}<4 \mathrm{mg} / \mathrm{l}=1, \mathrm{RBP} \geqslant 4 \mathrm{mg} / 1=2 ; \ddagger$ hazard ratio $=$ age $(x+10) / \times: \mathrm{RBP}$ $(\geqslant 4 /<4)$. normal distributions were used when the expected number of deaths was $\geqslant 30$ and approximation equations with Poisson distribution when the expected number of deaths was $<30 .{ }^{5}$ Also, the SMR of the RBP positive and negative groups were compared by the method of Fukutomi et al. ${ }^{6}$

\section{Results}

Positive urinary RBP showed a significant relation to mortality in both sexes by Cox's proportional hazard model (table 2). At this time, the mortality risk ratio (hazard ratio) of the RBP positive group to the RBP negative group was 1.71 for men and 1.42 for women.

Table 3 shows the SMRs according to causes of death in all men, RBP positive men, and RBP negative men. Although there was no significant difference, the SMR for all causes in all men was lower than that of the overall Japanese population. For all men the SMR for ischaemic heart disease was significantly lower, and SMRs for renal diseases and senility were significantly higher than those of the overall Japanese population. In the men the SMRs of the urinary RBP positive group were higher than those of the overall Japanese population for diabetes mellitus, cardiovascular diseases, respiratory diseases, renal diseases, and senility. These were also significantly higher in the urinary RBP negative group than in the overall Japanese population. Compared with the urinary RBP negative group, SMRs for cardiovascular diseases, respiratory diseases, and renal diseases were significantly higher in the urinary RBP positive group. The greater number of deaths from cardiovascular diseases were due to heart failure, and the SMR of the urinary RBP positive group for heart failure was significantly higher than that of the overall Japanese population or the urinary RBP negative group. A significant increase in SMR for cerebrovascular diseases was not found; however, the SMR for cerebral

Table 3 The causes of deaths among the inhabitants of an area polluted by $C d$

\begin{tabular}{|c|c|c|c|c|c|c|c|c|c|c|c|c|c|}
\hline \multirow[b]{3}{*}{ Causes of death } & \multirow[b]{3}{*}{$I C D N o$} & \multicolumn{6}{|l|}{ Men } & \multicolumn{6}{|c|}{ Women } \\
\hline & & \multicolumn{2}{|l|}{ Total } & \multicolumn{2}{|c|}{$\begin{array}{l}\text { Urinary RBP } \\
<4 \mathrm{mg} / \mathrm{l}\end{array}$} & \multicolumn{2}{|c|}{$\begin{array}{l}\text { Urinary } R B P \\
\geqslant 4 \mu g / l\end{array}$} & \multicolumn{2}{|c|}{ Total } & \multicolumn{2}{|c|}{$\begin{array}{l}\text { Urinary } R B P \\
<4 \mathrm{mg} / \mathrm{l}\end{array}$} & \multicolumn{2}{|c|}{$\begin{array}{l}\text { Urinary } R B P \\
\geqslant 4 \mu \mathrm{g} / 1\end{array}$} \\
\hline & & $O$ & $S M R$ & $O$ & $S M R$ & $O$ & $S M R$ & $O$ & $S M R$ & $O$ & $S M R$ & $O$ & $S M R$ \\
\hline All causes & 001-999 & 469 & $93 \cdot 5$ & 420 & $90 \cdot 3-^{\star}$ & 49 & $134 \cdot 5^{\star \star \star \star \neq \ddagger ~}$ & 461 & $101 \cdot 0$ & 373 & $98 \cdot 7$ & 88 & $156 \cdot 1^{\star \star \star}$ 持护 \\
\hline Infectious diseases & 001-139 & 12 & $124 \cdot 6$ & 12 & $133 \cdot 7$ & 0 & 0 & 4 & $68 \cdot 2$ & 3 & $15 \cdot 6$ & 1 & 154.4 \\
\hline Malignant neoplasms & $140-208$ & 109 & $82 \cdot 4$ & 104 & $83 \cdot 5-\star$ & 5 & $64 \cdot 0$ & 68 & $80 \cdot 3-+$ & 61 & $79 \cdot 5-+$ & 7 & $100 \cdot 1$ \\
\hline Stomach & 151 & 39 & $95 \cdot 1$ & 38 & $98 \cdot 8$ & 1 & $39 \cdot 7$ & 21 & $87 \cdot 6$ & 19 & $87 \cdot 0$ & 2 & 93.2 \\
\hline Trachea, bronchus, lung & 162 & 16 & $60 \cdot 9-\star$ & 16 & $64 \cdot 7-^{\star}$ & 0 & 0 & 6 & 64.9 & 6 & $70 \cdot 5$ & 0 & 0 \\
\hline Diabetes mellitus & 250 & 5 & $85 \cdot 1$ & 4 & $73 \cdot 0$ & 1 & $249 \cdot 3$ & 9 & $124 \cdot 4$ & 4 & 59.9 & 5 & $731 \cdot 5^{\star \star \star}$ 捺 \\
\hline Cardiovascular diseases & $390-429$ & 90 & $90 \cdot 7$ & 76 & $83 \cdot 0-\star$ & 14 & $182 \cdot 0^{\star \star \star}$ 护 & 124 & 116.4 & 96 & 103.9 & 28 & $197 \cdot 2^{\star \star \star \star}=$ \\
\hline Ischaemic heart diseases & $410-414$ & 24 & $63 \cdot 2-^{\star}$ & 22 & $62 \cdot 5-\star$ & 2 & 71.9 & 28 & $82 \cdot 6$ & 25 & $86 \cdot 5$ & 3 & $71 \cdot 1$ \\
\hline Heart failure & 428 & 52 & $122 \cdot 5$ & 42 & $38 \cdot 1-\star$ & 10 & 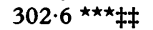 & 86 & $179 \cdot 1 \star \star \star$ & 63 & 155.9 * & 23 & $353 \cdot 0^{\star} t$ \\
\hline \multirow{3}{*}{$\begin{array}{l}\text { Cerebrovascular diseases } \\
\text { Cerebral haemorrage } \\
\text { Cerebral infarction }\end{array}$} & $430-438$ & 98 & $101 \cdot 4$ & 88 & 98.9 & 10 & $130 \cdot 0$ & 85 & $75 \cdot 1$ & 71 & $72 \cdot 4$ & 14 & 92.6 \\
\hline & $\begin{array}{l}431-432 \\
433,434\end{array}$ & 22 & $69 \cdot 2-+$ & 21 & $71 \cdot 1$ & 1 & $44 \cdot 1$ & 21 & $68 \cdot 7$ & 19 & $65 \cdot 2-\star$ & 2 & $56 \cdot 0$ \\
\hline & 437.7A,B & 67 & $123 \cdot 2$ & 58 & $116 \cdot 6$ & 9 & $193 \cdot 5 \star$ & 55 & $98 \cdot 2$ & 45 & $98 \cdot 7$ & 10 & $123 \cdot 7$ \\
\hline Respiratory diseases & $460-519$ & 51 & $104 \cdot 4$ & 43 & $95 \cdot 7$ & 8 & $206 \cdot 1^{\star} \neq$ & 28 & $82 \cdot \overline{8}$ & 23 & $78 \cdot 7$ & 5 & $108 \cdot 4$ \\
\hline Digestive diseases & $520-579$ & 22 & $116 \cdot 6$ & 22 & 124.9 & 0 & $0+$ & 24 & $165 \cdot 8$ * & 22 & $171 \cdot 6$ * & 2 & $120 \cdot 3$ \\
\hline Kidney and urinary diseases & $580-599$ & 15 & $167 \cdot 0$ * & 11 & 131.8 & 4 & $627 \cdot 6^{\star \star \star \star} \neq \ddagger$ & 17 & $163 \cdot 2$ * & 12 & $134 \cdot 7$ & 5 & $432 \cdot 5 \star \star \star \ddagger$ \\
\hline Nephritis and nephrosis & $580-589$ & 13 & $173 \cdot 2 \star$ & 9 & $128 \cdot 6$ & 4 & $790 \cdot 5$ * & 11 & $140 \cdot \overline{4}$ & 6 & $85 \cdot 6$ & 5 & $621 \cdot 5 \star \star \star \ddagger$ \\
\hline Urinary tract diseases & $590-599$ & 2 & $135 \cdot 2$ & 2 & $148 \cdot 4$ & 0 & 0.0 & 6 & $232 \cdot 4^{\star}$ & 6 & $259 \cdot 8$ * & 0 & 0.0 \\
\hline Senility & & $2 \overline{6}$ & $178 \cdot 0$ * & $2 \overline{1}$ & $162 \cdot 1$ * & 5 & $303 \cdot 0$ * & 67 & $249 \cdot 2^{\star \star \star}$ & 51 & $238 \cdot 0 \star \star \star \star$ & 16 & $293 \cdot 5^{\star \star \star}$ \\
\hline Accident and suicide & E800-999 & 26 & $135 \cdot 7+$ & 25 & $138 \cdot 7+$ & 1 & $88 \cdot 6$ & 20 & $140 \cdot 0+$ & 17 & $131 \cdot 4$ & 3 & $221 \cdot 9$ \\
\hline
\end{tabular}

$+\mathrm{P}<0.1 ;{ }^{\star} \mathrm{P}<0.05 ;{ }^{\star \star \star} \mathrm{P}<0.001$ significantly greater than the SMR of Japanese general population;

$\ddagger P<0.05 ; \ddagger \ddagger P<0.01 ;$; 㧊 $P<0.001$ significant difference between the SMRs of the two $R B P$ groups. $-\star P<0.05$ significantly less than $\ldots$. etc. $O=$ observed. 
infarction in the urinary RBP positive group was higher than that of the overall Japanese population, although no significant difference was found between the urinary RBP positive and negative groups. With regard to renal diseases, the SMR for nephritis and nephrosis was significantly higher in the urinary RBP positive than the negative group and the overall Japanese population.

Table 3 also shows the SMRs according to causes of death for women. The SMR for all causes in all women was not different from that of the overall Japanese population, but SMRs for digestive diseases, renal diseases, and senility were significantly higher than those of the overall Japanese population. Although a significant increase in the SMR of all women for cardiovascular diseases was not found, the SMR for heart failure was significantly higher than that of the Japanese general population. In the women, the SMRs of the urinary RBP positive group were higher than those of the overall Japanese population for diabetes mellitus, cardiovascular diseases, diseases of the kidneys and urinary system, and senility, whereas only the SMRs for diseases of the digestive system and senility were significantly higher in the urinary RBP negative group than in the overall Japanese population. The SMRs for diabetes mellitus, cardiovascular diseases, and renal diseases were significantly higher in the urinary RBP positive than the negative group in the women. The SMR for heart failure was higher in both urinary RBP positive and negative groups than in the overall Japanese population, with the increase in the SMR more obvious in the urinary RBP positive group, and the SMR in this group was significantly higher than in the RBP negative group. A significant increase in the SMR of the urinary RBP positive group of women for nephritis and nephrosis was found compared with the RBP negative group and the overall Japanese population.

\section{Discussion}

In 1974-5 Ishikawa Prefecture conducted the first health impact survey, measured the RBP concentration in morning urine samples, and found a clear increase in the frequency of abnormally high concentrations. ${ }^{1}$ Nogawa et al showed a probit regression line between urinary $\mathrm{RBP} \geqslant 4 \mathrm{mg} / \mathrm{l}$ and the average $\mathrm{Cd}$ concentration in rice for each hamlet, and found a dose-response relation between them. ${ }^{7}$ In 1981-2, the second health impact survey was conducted. Urinary $\beta_{2}$-microglobulin, and urinary $C d$ were measured in that survey, and a high prevalence of abnormal values was found. ${ }^{8}$ Ishizaki et al also showed a dose response relation between urinary $\beta_{2^{-}}$ microglobulin and urinary $\mathrm{Cd}$ in this survey. ${ }^{9}$ In this way, it has been convincingly shown that high prevalence of proximal tubular dysfunction found in the inhabitants of the Kakehashi River basin is attributable to $\mathrm{Cd}$ pollution.

In the seven year follow up study of the same subjects investigated here an increased mortality was found in the urinary RBP positive group only in the men, ${ }^{2}$ whereas in our study in which the observation period was extended to 15 years increased mortalities were found in both sexes in the urinary RBP positive group. These results are similar to those of the report of the 1981-2 Cd health impact survey in which the subjects were followed up for about nine years and in which the prognosis of the urinary $\beta_{2}$-microglobulin positive group was shown to be unfavourable. ${ }^{3}$ Also, in a 13-15 year follow up survey of Kosaka town in Akita Prefecture, another region polluted by $\mathrm{Cd}$ in Japan, the prognosis of the female inhabitants with positive urinary $\beta_{2}$-microglobulin was shown to be unfavourable. ${ }^{10}$

By contrast, in the reports of Shigematsu et al SMRs were significantly lower in towns and villages in the areas polluted by $\mathrm{Cd}$. We conducted a case control study of subjects with itai-itai disease and with suspected disease in the Jinzu River basin, located in Toyama Prefecture, and found high mortalities in both groups. ${ }^{13}$ These discordant results are thought to be due to the fact that Shigematsu et al compared a plains area (the polluted area) and a mountainous area (control area), where overall mortalities differ in Japan.

An interesting issue is whether or not the increased mortalities found in areas polluted by $\mathrm{Cd}$ are due to increases in mortalities for specific diseases. Of the previously conducted surveys on causes of death in regions in Japan polluted by Cd, that of Shigematsu et al found significantly lower SMRs for heart disease, hypertensive diseases, and cerebrovascular diseases in areas polluted by Cd than in control areas. ${ }^{112}$ In the polluted Kakehashi River basin in Ishikawa Prefecture studied here, deaths from cardiovascular diseases, especially heart failure, accounted for most of the deaths, with the data on cardiovascular and cerebrovascular diseases differing from those described in the report of Shigematsu et al. ${ }^{11} 12$

Although blood pressure values in the inhabitants of the Kakehashi River basin have not yet been determined, Nogawa and Kawano previously reported that blood pressure was lower in patients with itai-itai disease who live in the Jinzu River basin of Toyama Prefecture than in controls. In our study, no increase was found in the SMRs for hypertensive diseases and cerebral haemorrhage, which are closely associated with hypertension, which indicates that mortalities relating to hypertension may be decreased in this population. On the other hand, in Japan it is customary to ascribe the cause of death to heart failure in cases with no other clear cut cause of death or in those that show a gradual deterioration culminating in death, and this practice may be one factor accounting for the high mortalities for heart failure found in this study.

High morbidities for chronic bronchitis and emphysema, ${ }^{15}$ and high mortality for bronchitis $^{16}$ have been reported in factory workers exposed to $\mathrm{Cd}$, and in our study, also SMR for respiratory disease was significantly higher 
in the men. As the excessive mortality due to respiratory disease found in our study was mainly due to pneumonia and bronchitis and the route of $\mathrm{Cd}$ exposure differed from that of factory workers, it is considered that these deaths may not have been due to a direct influence of $\mathrm{Cd}$ but rather to a worsening of the general state of health.

In our study we found a high SMR for renal diseases, in particular nephritis and nephrosis, and in the study of Shigematsu et al SMR for uraemia was significantly increased. ${ }^{112}$ In the Kakehashi River basin targeted in our study, the SMR for diabetes mellitus was also high in the women. Most of the deaths from diabetes occurred early in the observation period when renal dysfunction induced by $\mathrm{Cd}$ was not recognised. Renal dysfunction due to $\mathrm{Cd}$ is often accompanied by raised urinary glucose. Diabetes may have been mistakenly diagnosed in some of these subjects. Lauwerys et al reported frequent deaths from renal disease among inhabitants with a long history of exposure in regions polluted by $\mathrm{Cd}$ in Belgium, and Elinder et $a l^{18}$ and Kjellstrom et al $^{19}$ in a study of mortalities in factory workers exposed to Cd found significantly high values for deaths due to nephritis and nephrosis. These findings suggest that subjects with renal tubular disorder induced by $\mathrm{Cd}$ may have advanced renal dysfunction and be at high risk of premature death.

In studies on causes of death in factory workers the impact or lack of impact of Cd on mortality from malignant neoplasms, particularly prostate and lung cancers, has become an issue. ${ }^{1820-22}$ In our study the number of deaths was small and it was not possible to determine cancer mortalities according to site. A longer follow up period is necessary to evaluate this.

1 Tsuchiya K, Sakurai H, Shigematu I, et al. Epidemiological studies. In: Tsuchiya K, ed. Cadmium studies in fapan. A review. Tokyo: Kodansha, 1978: studies in

2 Nakagawa H, Kawano S, Okumura T, Fujita T, Nishi $M$ Mortality study of inhabitants in a cadmium-polluted area. Bull Environ Contam Toxicol 1987;38:553-60.
3 Nakagawa $H$, Nishijo $M$, Morikawa $Y$, Tabata $M$, Senma $M$, Kitagawa $\mathrm{Y}$, et al. Urinary $\beta_{2}$-microglobulin concentration and mortality in a cadmium-polluted area. Arch Environ Health 1993;48:428-435.

4 Cox DR. Regression models and life tables. Fournal of the Royal Statistical Society (B) 1972;34:187-220.

5 Armitage A. Standardization. In: Armitage A, ed. Statistical method in medical research. Oxford: Blackwell Statistical method in medical research.

6 Fukutomi K, Hashimoto S. Some remarks on the standardized mortality ratio. fapanese fournal of Public Health 1989;36:155-60. (In Japanese.)

7 Nogawa K, Ishizaki A, Kawano S. Statistical observations of the dose-response relationships of cadmium based on epidemiological studies in the Kakehashi River basin. Environ Res 1978;15:185-98.

8 Kido T, Honda R, Tsuritani I, Yamaya Y, Ishizaki M, Yamada $\mathrm{Y}$, et al. An epidemiological study on renal dysfunction of inhabitants in Cd-exposed areas in Kakehashi River basin in Ishikawa Prefecture. Fapanese fournal of Hygiene 1987;42:964-72. (In Japanese.)

9 Ishizaki M, Kido T, Honda H, Tsuritani I, Yamada Y, Nakagawa $\mathrm{H}$, et al. Dose-response relation between urinary cadmium and $\beta_{2}$-microglobulin in a Japanese envinary cadmium and $\beta_{2}$-microglobulin in a Japanese environmentally cadmi

10 Iwata K, Saito H, Moriyama M, Nakano A. Follow up study of renal tubular dysfunction and mortality in residents of an area polluted with cadmium. $\mathrm{Br} \mathcal{F}$ Ind $\mathrm{Med}$ 1992;49:736-7.

11 Shigematsu I, Takeuchi J, Minowa $M$, Nagai M, Usui T, Fukushima $\mathbf{M}$, et al. A retrospective mortality study on cadmium exposed pollution in Japan. Kankyo Hoken Report 1980;46:1-71. (In Japanese.)

12 Shigematsu I, Minowa $M$, Nagai $M$, Omura $T$, Takeuchi K. A retrospective mortality study on cadmium-exposed pollution in Japan: an investigation of mortality rates by a pollution in Japan: an investigation of mortality rates by pollution level in Toyama Prefecture. Kan

13 Nakagawa H, Tabata M, Morikawa Y, Senma $M$ Kitagawa Y, Kawano S. High mortality and shortened Kitagawa Y, Kawano S. High mortality and shortened life-span in patients with itai-itai disease and subjects
with suspected disease. Arch Environ Health with suspected

14 Nogawa K, Kawano S. A survey of the blood pressure of woman suspected of itai-itai disease. Fournal of the fuzen Medical Society 1969;77:357-63. (In Japanese.)

15 Armstrong BG, Kazantzis G. Prostatic cancer and chronic respiratory and renal disease in British cadmium workers: a case-control study. Brf Ind Med 1985;42:540-5.

16 Armstrong BG, Kazantzis G. The mortality of cadmium workers. Lancet 1983;25:1425-7.

17 Lauwerys $R$, De Wals. Environmental pollution by cadmium and mortality from renal diseases. Lancet 1981;i: mium.

18 Elinder CG, Kjellstrom T, Hogsted C, Andersson $\mathrm{K}$, Spang G. Cancer mortality of cadmium workers. $\mathrm{Br} f$ Ind Med 1985;42:651-5.

19 Kjellstrom T, Friberg L, Rahnster B. Mortality and cancer morbidity among cadmium-exposed workers. Environ Health Perspect 1979;28:199-204.

20 Thun MJ, Schnorr TM, Smith AB, Halperin WE, Lemen RA. Mortality among a cohort of US cadmium production workers. $\mathcal{F}$ Natl Cancer Inst 1985;74:325-33.

21 Ades AE, Kazantzis G. Lung cancer in a non-ferrous smelter: the role of cadmium. $\mathrm{Br} f$ Ind $\mathrm{Med}$ 1988;45:435-44.

22 Sorahan T. Mortality from lung cancer among a cohort of nickel cadmium battery workers: 1946-84. Br f Ind Med 1987;44:803-9.

\section{Rejected manuscripts}

From February 1994, authors whose submitted articles are rejected will be advised of the decision and one copy of the article, together with any reviewers' comments, will be returned to them. The fournal will destroy remaining copies of the article but correspondence and reviewers' comments will be kept. 